\title{
RHETORIC OR REALITY? RECASTING LOCAL GOVERNMENT'S PURPOSE AND ROLE
}

\author{
DEAN R KNIGHT*
}

\section{A. Introduction}

An amendment in 2012 changed the purpose of local government in New Zealand from the promotion of community well-beings to the provision of local infrastructure, local public services and regulatory functions. This change, enacted by the Local Government Act 2002 Amendment Act 2012 ("LG Amendment Act 2012"), was heralded by the government as a move to "refocus" the purpose of local government; the reform would ensure local authorities concentrate on delivering those services that were most appropriately undertaken by local government. ${ }^{1}$ Potential targets for this rationalisation were events like flower shows and sports car races, economic development and other commercial ventures, along with measures with a social or welfare focus such as educational goals and community identity initiatives.

But did the amendment actually achieve this?

In this legislative note, I conclude that it did not. A careful analysis of the legislative text, along with the related parliamentary and other law reform material, shows that the reforms were strong on rhetoric but in reality changed little. Although the new language is ambiguous, the better view is that local government continues to have a broad mandate. Activities previously justified in the name of the promotion of community well-beings will generally still be able to be undertaken under the ambit of the recast purpose.

\section{B. From Promotion of Well-Beings to Delivery of Local Public Services}

The purpose of local government, as set out in s 10 of the Local Government Act 2002 ("LG Act 2002"), has an overarching and instrumental role in shaping the nature and activities of local authorities. As a matter of law, the types of activities that may be undertaken by local authorities links back to the purpose of local government. Following the 2012 amendment, s 10(1) provides:

(1) The purpose of local government is-

(a) to enable democratic local decision-making and action by, and on behalf of, communities; and

(b) to meet the current and future needs of communities for goodquality local infrastructure, local public services, and performance of regulatory functions in a way that is most cost-effective for households and businesses.

* Senior Lecturer, Faculty of Law; Co-Director, New Zealand Centre for Public Law; Victoria University of Wellington (dean.knight@vuw.ac.nz). Thanks, subject to the usual caveat, to Chris Mitchell for comments on a draft version of this article and Luke Archer for research assistance.

1 See Hon David Carter (12 June 2012) 680 NZPD 2839; Hon Chester Borrows (15 November 2012) 685 NZPD 6735; Hon Maurice Williamson (29 November 2012) 66 NZPD 6955. 
This provision is one of the foundations of the LG Act 2002. It has two principal components. The first is an emphasis on representative and participatory democracy, that is, how local authorities should operate. The second is the identification of the permissible functions of local authorities, in other words, what local authorities can and should do.

Section 10(1)(b) effectively sets the parameters for the activities that a local authority can lawfully undertake. Under s 11 the role of a local authority is to "give effect" to the purpose of local government. The power of general competence in s 12 is framed by reference to the role of a local authority and therefore the purpose of local government: a local authority has "full capacity" to undertake activities and so forth, but only "[f]or the purpose of performing its role".

When originally enacted in 2002, s 10(1)(b) mandated local authorities in general terms:

(b) to promote the social, economic, environmental, and cultural well-being of communities, in the present and for the future.

However, fuelled by perceived concerns about the burgeoning activities of local government, the National-led government recast the generalised purpose into a more specific - and purportedly narrower - terms. ${ }^{2}$ The amended purpose provision identifies three permissible functions:

(a) "local infrastructure";

(b) "local public services"; and

(c) "regulatory functions".

The lawfulness of a particular activity will therefore turn on whether the activity falls within one of those functions; if not, it risks being invalidated.

Some further points to note about the manner in which the purpose clause is expressed. First, the active part of s 10(1)(b) is, in fact, to "meet the current and future needs of communities". However, this is conditioned by the passive reference to the particular needs that are to be met, namely, the three permissible functions. Hence, it is the three permissible functions that effectively form the boundaries of lawful local authority action. Secondly, the permissible functions are required to be "good-quality" and provided in a way that is "most cost-effective for households and businesses." Neither of these adjectives alter the boundaries of permissible functions in any substantive way. These terms have a relative and subjective character; there is no prospect, except perhaps in the most extreme circumstances, of a court basing a ruling of illegality on an assessment of non-compliance with these qualifiers. Thirdly, in general terms, the recasting of the purpose of local government is represented by a change from an outcome focus (community well-beings) to an output focus (infrastructure, services, regulatory functions), along with an input constraint (cost-effectiveness).

To repeat, lawfulness depends on the meanings of local public services, regulatory functions, or local infrastructure. But the specification of these functions does not provide clear guidance.

2 Cabinet Paper "Better Local Government" (19 March 2012); Department of Internal Affairs Better Local Government (Reform Programme Paper, 2012). For a discussion of earlier efforts to re-focus local authorities on core activities, see Mike Reid "The Problem with Defining Core Services" (2009) 5(4) Policy Quarterly 46. 
There may be some overlap between the three permissible functions, but it is convenient to analyse each separately. The greatest ambiguity arises in relation to the meaning of "local public services"; the terms "regulatory functions" and "local infrastructure" do not raise significant legal issues about their scope:

(a) Terms like "local" and "public" are ambiguous and hollow words. They are not defined and their meaning is not immediately obvious. They are capable of being interpreted either narrowly or broadly. Ultimately, as discussed below, they turn on one's political ideology and theory of the state.

(b) The reference to regulatory functions adds little to the scope of the activities that can be undertaken. Because regulatory functions are coercive, they must be empowered by specific legislative provisions. ${ }^{3}$ The reference here to these functions does not provide a general, free-standing power to regulate. Answers about lawfulness therefore fall for consideration elsewhere, where other legislative provisions authorise specific regulatory activities.

(c) "Local infrastructure" carries a particular and traditional meaning within local government legislation. ${ }^{4}$ The references to "local" and "public" in the context of infrastructure may raise some issues though and the discussion below about those terms is equally applicable.

It follows that controversial activities will generally need to be justified by reference to the meaning of "local public services".

In the analysis that follows, I consider the meaning of the phrase by reference to the text of each word first, followed by the context and purpose of the provision. Before moving to this analysis, however, it is important to note some caveats. First, for the purposes of this analysis, I am adopting the traditional approach in New Zealand law as to the interpretation of jurisdictional provisions. That is, if the lawfulness of activities of a public body is challenged, the courts will determine whether the public body has the power to undertake those activities by determining the legal meaning of the words in the provision conferring that power. In doing so, they will consider the text and purpose of the provision. ${ }^{5}$ The courts will assess compliance strictly, effectively applying a correctness standard. In other words, because lawfulness turns on the scope of legal meaning, the courts will not afford any latitude to the local authority's own assessment of the meaning of those words or whether its activities fall within the meaning of those words. ${ }^{6}$ (I return to this point later following the analysis, arguing that this is one of the situations where the courts should consider exercising a degree of latitude.) Secondly, I am not ignoring the fact that questions about meaning and scope may arise elsewhere. Obviously, the meaning of the terms will fall to be considered in the deliberations of local authorities themselves. Further, other

3 See for example, New Health New Zealand Inc v South Taranaki District Council [2014] NZHC 395, [2014] 2 NZLR 834 at [41].

4 Network infrastructure covers "roads and other transport, water, wastewater, and stormwater"; community infrastructure is defined as land and assets used to provide public amenities: Local Government Act 2002 ("LG Act 2002"), s 197(2).

5 Interpretation Act 1999, s 5 and for example, Commerce Commission v Fonterra Co-operative Group Ltd [2007] NZSC 36, [2007] 3 NZLR 767.

6 Bulk Gas Users Group v Attorney-General [1983] NZLR 129 (CA); Peters v Davison [1999] 2 NZLR 164 (CA). 
supervisory agencies such as the Auditor-General or Ombudsman may be called on to express an opinion on the scope of permissible functions in the course of their audits or investigations. However, the lens I am adopting here is a legal one, which, in accordance with the New Zealand legal tradition, ultimately falls for determination by the courts.

\section{The Likely Meaning of "Local Public Services"}

Looking at the text, context and purpose of "local public services" (in that order), the phrase is unclear, but a broad interpretation is generally favoured. In other words, when read in the light of the usual indicators of meaning, the reformed meaning centred around local public services does not differ much from its community well-being predecessor - despite the change in terminology.

\section{Text}

The first component is the term "local". "Local" contrasts, in this context, with "national" - particularly, public services that could or should be delivered at a national or nation-wide level. The distinction is not merely spatial or defined by reference to services undertaken within the district (for example, ss 11(a) and 12(4) and 12(6) address questions of spatial territoriality in the provision of services). When read in context, the term "local" seeks to express a judgement about the nature of the activity being undertaken and the circumstances in which it is normatively appropriate for that activity to be undertaken by a sub-national local authority. As a matter of linguistics, though, the term "local" does not provide an obvious or definitive boundary. Ultimately, the meaning of the term turns on socio-political factors and ideological attitudes about the shape and nature of the state, particularly the subsidiarity principle. ${ }^{7}$

The second component is the term "public", on which much turns. The reference to "public" contrasts, in this context, with "private". Again, the term does not manifest obvious or definitive boundaries. The dictionary definition is inconclusive: ${ }^{8}$

public adj 1 of, concerning, or open to the people as a whole. $\mathbf{a n v o l v e d ~ i n ~}$ the affairs of the community, especially in government or entertainment ... $\mathbf{3}$ of or provided by the state rather than an independent commercial company.

These definitions, while broadly stated, add little flavour. They merely restate the focus on the community and state, and repeat the contradistinction with activities undertaken by private bodies.

At a broader level, the meaning of the term "public", again, turns on socio-political factors and ideological attitudes about the shape and nature of the state, rather than intrinsic characteristics of the activity. ${ }^{9}$ The term public is ultimately a contested concept. It operates like a "floating signifier", capable of being imbued with narrow or broad meanings, depending on the whims of the person deploying the term. There is no one right answer as to its meaning; both the narrow and broad meanings are plausible. In this context, therefore, the

7 See for example the debates about how to allocate function in the development of a super city for Auckland: Royal Commission on Auckland Governance Report (March 2009).

8 Concise Oxford Dictionary (12th ed, Oxford University Press, Oxford, 2011).

9 For the importance of theory of the state in public law, see Carol Harlow and Richard Rawlings Law and Administration (2nd ed, Butterworths, London, 1997) at 1. 
meaning can only be determined by reference to the purpose and broader context of the provision.

I recognise there are a number of administrative law and human rights cases that have assessed whether certain functions can be treated as "public functions", but I do not consider these cases as directly applicable to the present issue. ${ }^{10}$ The essential question in that line of authority is whether the activities of a private entity are sufficiently public in character for them to be subjected to public law norms and controls. The general thrust of these cases is that the question is ultimately one of evaluation based on the particular circumstances. The factors or indicia that are usually regarded as relevant to this assessment include matters such as the recognition of the function in the statutory scheme, sources of funding, comparative experience abroad and across time, effect of function on the public, and means of accountability or control of the function. These cases are helpful in demonstrating that an assessment of "publicness" is a contextual one. But, importantly, the fundamental purpose of that assessment is different. It relates to the issue of the nature of accountability that should flow from functions that are being undertaken (typically) by private bodies or individuals. The line of cases does not speak directly to the interpretative question of who should undertake those activities. That critical difference means these cases are not directly relevant.

The final component is the term "services". It, too, is capable of being read both narrowly and broadly. On the one hand, it may be restricted to the direct provision of assistance to a person or people; on the other hand, it is capable being interpreted more broadly to include indirect provision of assistance, for example, through the creation of circumstances or an environment that assists a person or people. The text and dictionary definitions do not address this distinction, and it is necessary to turn to other indicators of meaning.

Overall, the text itself does not provide a firm direction about the meaning of the phrase "local public services" or its components: both the narrow and broad meanings are plausible. It is necessary therefore to pay particular attention to the context in which the phrase is deployed and its purpose.

\section{Statutory context}

The broader statutory context provides some hints as to the meaning of local public services. These generally favour giving the phrase a broad meaning.

The most significant contextual factor within the LG Act 2002 is the enumerated list of "core services" in s 11A. First, the list of core services must be a limited subset of the functions listed in s 10; otherwise s 11A becomes redundant. The statement that there are "core" activities to which particular regard must be given suggests that there are other activities that fall within s 10 . This is inconsistent with a narrow interpretation being given to the meaning of permissible functions in s 10 .

10 See for example $R v$ Panel on Take-overs and Mergers, ex parte Datafin Plc [1987] QB 815 (CA); Ransfield v The Radio Network [2005] 1 NZLR 233 (HC); Royal Australasian College of Surgeons v Phipps [1999] 3 NZLR 1 (CA); Peter Cane "Accountability and the Public/Private Distinction" in Nicholas Bamforth and Peter Leyland (eds) Public Law in a Multi-Layered Constitution (Hart Publishing, Oxford, 2003) 247; Mark Freedland and Jean-Bernard Auby (eds) The Public Law/Private Law Divide (Hart Publishing, Oxford, 2006); Mark Elliott "Judicial Review's Scope, Foundations and Purposes: Joining the Dots" [2012] NZ Law Rev 75 . 
The list of core services in s 11A of the LG Act 2002 also refers to particular services that are provided indirectly (that is, avoidance or mitigation of natural hazards; reserves; and community infrastructure). This augments the view that the term services is not restricted to assistance provided directly. Similarly, a provision in a schedule addressing Council-controlled organisation also refers to assistance provided indirectly (flood protection and control works) in a list of "services". ${ }^{11}$ While there is the occasional use of the term "amenities" separately from the term "services", suggestive perhaps of some distinction between direct and indirect assistance, it generally occurs where the term "services" is used in a different sense to its usage in $\mathrm{s} 10 .{ }^{12}$

Finally, the set of principles relating to local authorities listed in s 14 do not help resolve the question about the scope of permissible functions. Local authorities are obliged to act in accordance with principles such as democratic accountability, transparency, efficiency, prudence stewardship, sustainability, and so forth. However, these obligations are engaged when a local authority is "performing its role". So, the principles are, in that sense, subordinate and therefore cannot directly affect the jurisdictional boundaries within which local authorities can act. They may, of course, influence individual decisions made by local authorities about whether to undertake activities within that those boundaries, but they do not cast light on the delineation of the boundaries.

\section{Purpose}

Turning to purpose, the analysis moves beyond words and to the intentions of Parliament when enacting the legislative text. Purpose is a multifarious concept and can be gleaned from a number of different sources. ${ }^{13}$ In this context, the relevant indicators are the stated purposes of the legislation and the extrinsic material generated in the reform process. ${ }^{14}$ This material raises two different possible interpretations. The amendment may be treated as a circumscribing amendment, where the scope of activities is materially constrained from the broad well-beings statement in the original LG Act 2002. Alternatively, the amendment may merely be a symbolic amendment, where the amended wording in the purpose provision does not significantly affect the scope of activities.

In this case, the stated purpose of the LG Act 2002 provides some weak support for a broad interpretation. The extrinsic material traditionally relied on by the courts to ascertain meaning (explanatory note, sponsoring Minister's speeches, and select committee report) is generally silent or inconclusive; other parliamentary material is mixed either way. The strongest hints are found in the departmental material, which leans towards a symbolic amendment only.

The purpose of the LG Act 2002 itself (as amended by the LG Amendment Act 2012) contains a couple of (weak) indicators that the phrase local public services ought to be given a broad meaning. Section $3(\mathrm{~b})$ refers to providing

11 LG Act 2002, sch 8, cl 10.

12 See for example, LG Act 2002, ss 150(6) and 197.

13 John Burrows and Ross Carter, Statute Law in New Zealand (4th ed, LexisNexis, Wellington, 2009) at 219-222.

14 Marac Life Assurance Ltd v Commissioner of Inland Revenue [1986] 1 NZLR 694 (CA) and Catherine J Iorns-Magallanes "The 'Just Do It' Approach to Using Parliamentary History Materials in Statutory Interpretation" (2009) 15 Canta LR 205. The persuasiveness of this extrinsic material varies, depending on how definitive and authoritative the various material is. 
"a framework and powers for local authorities to decide which activities they undertake". This implicitly emphasises the choice or judgement available to local authorities when deciding the activities they undertake, rather than being prescriptive about the parameters of those powers. Further, s 3(d) refers to local authorities "play[ing] a broad role" in meeting the needs of their communities, albeit then much of the text of the purpose provision is reproduced, including the three permissible functions. Both tend to favour a benevolent reading of scope, although neither is particularly strong. The LG Amendment Act 2012 does not state its purpose, although the usual presumption is that amendments have some instrumental effect. As mentioned above, it is therefore necessary to canvas extrinsic material for stronger indicators of the purpose of the reforms.

The parliamentary material is generally mixed and equivocal. First, indications in the explanatory note were mixed..$^{15}$ The general policy statement in the explanatory note made various references to "(re)focusing" and "reframing" local government. Notably, the desirability of local authorities "delivering those services that only councils can provide or performing those roles that only councils can perform"16 and objection to local authorities diverting "into areas already covered by central government and the private sector" were mentioned. ${ }^{17}$ This reinforces the rhetoric on which the reforms were premised. Otherwise, the general policy statement merely repeated the text of the amended purpose provision. Further, the clause-by-clause analysis merely signalled the change, without substantive comment.

Secondly, the Select Committee report discussed the general nature of the reform but did not clarify the purpose in detail. ${ }^{18}$ The Local Government and Environment Committee was divided on the Bill, particularly the wording of the amended purpose. Those members supporting the amendment did not address the point; those opposing raised some concerns, but it is impossible to ascertain whether the concerns were well-founded. In the joint commentary, there is some equivocal mention of concerns made by submitters. On the one hand, the report acknowledged that concerns were expressed about the potential narrowing of the scope of local authority activities, including risk that it might threaten "the maintenance of local government activities that foster community cohesion and welfare." 19 On the other hand, the report notes submissions that suggested the amendment would not have any material effect on the scope of local government activities. The intended effect was not, however, clarified. The separate commentaries contained limited analysis. Government members commend the changes, but did not address the content or effect of them. Labour members only addressed the robustness of the claimed problem-diagnosis and did not address the legislative language adopted. Green members expressed concern that the new purpose "does not accurately describe the role of local government", repeating concerns from submitters about the effect on "place making" and other social roles of local authorities. ${ }^{20}$ The New Zealand First

\footnotetext{
15 Local Government Act 2002 Amendment Bill 2012 (27-2) (explanatory note).

16 Local Government Act 2002 Amendment Bill 2012 (27-2) (explanatory note) at 1.

17 Local Government Act 2002 Amendment Bill 2012 (27-2) (explanatory note) at 2.

18 Local Government Act 2002 Amendment Bill 2012 (27-2) (select committee report).

19 Local Government Act 2002 Amendment Bill 2012 (27-2) (select committee report) at 2.

20 Local Government Act 2002 Amendment Bill 2012 (27-2) (select committee report) at 13.
} 
member similarly expressed concern about the potential effect on economic well-being, in particular initiatives to attract business and enterprise to regions. Ultimately, therefore, the Select Committee material is relatively inconclusive.

Thirdly, the Bill was amended by a Supplementary Order Paper ("SOP") to give effect to amendments recommended by government members on the Select Committee (necessary, as the Committee could not produce a majority view). However, the SOP did not amend or discuss the purpose provision.

Fourthly, the parliamentary debates were vociferous, particularly on the amended purpose. ${ }^{21}$ However, the debates do not bring clarity to the intended meaning. The Minister's speeches (including the speeches given on his behalf in the Second and Third reading) were relatively uninformative. Generally, they referred to the refocusing of the purpose provision, recited the amended wording and, ironically, championed the proposed "clear and focused purpose statement"; there was also occasional reference to local authorities "doing things that only they can do." 22 The most telling explanation was Hon Chester Borrows' speech, given on the Minister's behalf in the Second Reading: ${ }^{23}$

I firmly believe a more focused mandate for local government is necessary. The intention is not to prescribe what local authorities can and cannot do, but rather to better define the appropriate scope of their activities. Individual local authorities and their communities will decide what activities matter to them and how much they are willing to pay for them. The new purpose statement will encourage local authorities to take a fresh look at what they are doing and why, and to seek their community's guidance as to what their current and future needs are.

While the passage speaks of redefinition of activities, it also emphasises community input and council judgement - hinting at a continuing broad definition. Speeches from other members were mixed, including those speaking on behalf of the Government. It is therefore difficult to discern any reliable indications from these speeches to assist the interpretative process. By way of example, on the one hand, remarks from Hon Dr Nick Smith (notably, a former Minister of Local Government) were consistent with the amendment having a limiting nature, such as listing activities that he said would be impermissible (for example, running steel mills, corner dairies, and farms) and those which would be permissible (for example, libraries and parks). On the other hand, members such as Nicky Wagner (chair of the relevant Select Committee) and Jacquie Dean suggested the amended purpose provision would not unduly constrain local government. ${ }^{24}$ They said the new purpose would not prevent local authorities from investing in tourism, meeting halls, swimming pools, recreational facilities, and community houses.

The departmental analysis and other material that preceded the introduction of the Bill contained the most candid assessment of the nature of the amendment. This material generally supports reading the permissible functions generously and

21 (12 June 2012) 680 NZPD 2839 (first reading); (15 November 2012) 685 NZPD 6735 (second reading); (27 November 2012) 686 NZPD 6774 (Committee of the Whole); (29 November 2012) 686 NZPD 6955 (third reading).

22 (12 June 2012) 680 NZPD 2840 (first reading).

23 Hon Chester Borrows (15 November 2012) 685 NZPD 6736.

24 Nicky Wagner (27 November 2012) 686 NZPD 6776; Jacqui Dean (15 November 2012) 685 NZPD 6739, (27 November 2012) 686 NZPD 6795, (29 November 2012) 685 NZPD 6965. 
treating the amendment as a symbolic amendment that makes little instrumental change. First, the Regulatory Impact Statement contains the most clear and comprehensive statement about the effect of the Amendment Act, and suggests the change would only be "symbolic", not substantive. ${ }^{25}$ The problem identified with the previous purpose statement was that it provided "no direction as to what councils should be expected to do, and [was] too broad to offer useful parameters within which local government authority can be planned". ${ }^{26}$ In the analysis of the perceived problem, it said it was "questionable" whether certain activities, while meritorious, were best undertaken by local authorities. ${ }^{27}$ Activities such as "entering into commercial competitive businesses, running Lotto shops, setting targets for NCEA pass rates, developing strategies for improving the well-being of families" were specifically cited. ${ }^{28}$ Concern was expressed that the original broad purpose statement contributes to "risks which arise from expanding council scope ... because it can be used to justify any conceivable action." ${ }^{29}$ The solution to this, it was argued, was to "refocus the purpose of local government to provide for those services that are most appropriately undertaken by councils." ${ }^{30}$ It was claimed that doing so would "provide a means by which local government's core activities can be prioritised." ${ }^{31}$ However, in the discussion of the risks of the preferred approach, any unduly constraining effect of the amended purpose provision was rebutted; in particular it said: ${ }^{32}$

55. There may be some risk that deleting all references to the four well-beings may result in some councils emphasising some objectives at the expense of others. If too narrowly focused, a new purpose statement could also be interpreted as a signal to withdraw from activities that currently have a positive effect on the economy. However, the intention is not to preclude council involvement in activity that will get New Zealand's economy growing. The amended purpose statement will ensure councils can achieve a wide range of appropriate functions.

56. The change is likely to have a symbolic effect and should not affect council business as usual. The change should help the local government sector focus on those roles that only councils can deliver. Councils will

25 Department of Internal Affairs Better Local Government (Regulatory Impact Statement, 16 March 2012).

26 Department of Internal Affairs Better Local Government (Regulatory Impact Statement, 16 March 2012) at [21].

27 Department of Internal Affairs Better Local Government (Regulatory Impact Statement, 16 March 2012) at [37].

28 Department of Internal Affairs Better Local Government (Regulatory Impact Statement, 16 March 2012) at [37].

29 Department of Internal Affairs Better Local Government (Regulatory Impact Statement, 16 March 2012) at [37].

30 Department of Internal Affairs Better Local Government (Regulatory Impact Statement, 16 March 2012) at [38].

31 Department of Internal Affairs Better Local Government (Regulatory Impact Statement, 16 March 2012) at [38].

32 Department of Internal Affairs Better Local Government (Regulatory Impact Statement, 16 March 2012) at [55]-[56] (emphasis added). 
continue to ensure they promote good governance and decision-making by considering the needs and impacts in the future as well as the present.

This is instructive; it favours a broad interpretation and treatment of the amendment in symbolic terms only.

Secondly, the Cabinet papers did not elaborate on the issue in any great detail, sending mixed messages. The emphasis of the "Better Local Government" Cabinet Paper, then sponsored by Hon Dr Nick Smith, was on refocusing local government on "roles that only councils can deliver" and avoiding duplication with central government and the private sector. ${ }^{33}$ However, the Minister also noted that he did not expect the new purpose provision to be unduly restrictive. For example, he said "the amended purpose statement will not be so rigid as to prevent councils being able to continue a wide range of appropriate local government functions." 34

Thirdly, the government's original "Better Local Government" paper set out the government's reform programme. ${ }^{35}$ It was short and lacked detail on the issue. The explanation merely repeated the obvious textual dichotomies (local versus national; public versus private), and again shed little light on what those words mean in practice.

In summary, the material addressing the mischief and purpose of the Local Government Act 2002 Amendment Act 2012 is generally mixed and equivocal, although departmental analysis provides a reasonable degree of support for s 10 still carrying a broad meaning and the reforms being largely symbolic only.

\section{Conclusion}

In the end, the crucial boundary-setting words in the purpose of local government are ambiguous. The key terms - "local", "public", and "services" - lack any firm natural meaning. They are contested terms, which, in this context, depend on ideological factors and one's theory of the state. The general thrust of the LG Amendment Act 2012 was to encourage local authorities to focus on activities that only they could achieve (in contradistinction to national government and the private sector). However, a close examination of the text and supporting material suggest this was more rhetorical and symbolic. The amended purpose clause does not construct a rigid delineation between these spheres and emphasises a degree of choice and judgement being retained by local authorities.

As mentioned at the outset, for the purpose of this analysis, I have assumed that the meaning to be attributed to $\mathrm{s} 10$ is the meaning likely to be determined by courts applying their strict interpretative function. That is, no deference would apply to a local authority when forming its view on the scope of s 10 . However, the nature of the regime (open-textured wording; emphasis on local authority judgement; heavy emphasis on community engagement and democratic accountability, particularly in s 12(1)(a)(i), (b) and (2)) could support an argument that the courts ought to defer, to some degree, to the judgement made by the local authority, rather than applying a strict approach. While such an approach is presently unprecedented in New Zealand, the courts ought to

33 Cabinet Paper "Better Local Government” (19 March 2012) at [39].

34 Cabinet Paper "Better Local Government" (19 March 2012) at [38].

35 Department of Internal Affairs Better Local Government (Reform Programme Paper). 
consider affording some latitude to the assessment by local authorities about scope, meaning and compliance in this context.

Ultimately, it is unsatisfactory that the legislature provides such ambiguous direction as to the scope of the activity of public institutions. The dissonance between the rhetoric and reality of the reform is troubling. A benevolent view is that it was sloppy reform. A cynical view is that it was a deliberate ploy in order to be seen to be getting tough on a perceived bloated and out-of-control local government sector, while appreciating that radical reform of its purpose was neither necessary nor desirable. In either case, local government governance and decision-making is poorer for the recast purpose. Doubt is injected in the mandate of local government and, with it, uncertainty that carries cost, delay and risk. 